\title{
Population Differentiation in the Body Architecture of Creole Goats in the Semi Arid Region of Chile
}

\author{
Diferenciación Poblacional en la Arquitectura Corporal \\ de Cabras Criollas en la Región Semiárida de Chile
}

De la Barra, R. ${ }^{\text {; }}$ Carvajal, A. M. ${ }^{1}$ \& Martínez, M. E. ${ }^{2}$

\begin{abstract}
DE LA BARRA, R.; CARVAJAL, A. M. \& MARTíNEZ, M. E. Population differentiation in the body architecture of creole goats in the semi arid region of Chile. Int. J. Morphol., 37(2):690-693, 2019.

SUMMARY: The present study aimed to assess the degree of body architecture differentiation between Creole goats, two introduced breeds and their hybrids in semi arid areas of the north of Chile. The study was carried out between 2012 and 2015. One hundred and eighty five adult female goats belonging to 17 herds from the Coquimbo region were used. Ten animals of the Saanen breed and 10 animals of the Anglo nubian breed belonging to two hatcheries and 165 Creole and hybrid goats belonging to small farmers were measured. The animals were categorized into pure breed (20), hybrid (52) and creole (113). Eight body measurements were taken: head length (HL), head width (HW), longitudinal diameter (LD), bicostal diameter (BD), dorsal-sternal diameter (DSD), rump width (RW), rump length (RL) and whithers height (WH). Data were submitted to principal component analysis (PCA) and Fisher LSD test, using the XLSTAT-Pro Statistic software. The analysis indicated the existence of homogeneity subsets within the population, without a common architectural pattern for the entire population. The Creole biotype showed a smaller body architecture than the two breeds and hybrids with which it was compared, which could be an adaptative result. It is possible to assess that the Creole biotype has a differentiated body architecture with respect to the introduced goat breeds and the animals hybridized in different proportions. In addittion, it was observed that Creole goats maintain distinctive characteristics and they are differentiable even of the individuals with different degrees of hybridization.
\end{abstract}

KEY WORDS: Morphology; Goat; Population characteristics; Ethnology.

\section{INTRODUCTION}

Goats were introduced in America around the 16th century by the Spanish and Portuguese conquers (Arbiza Aguirre, 1986). Hundreds of years of breeding subjected to natural selection lead to a rustic animal that adapts to a wide range of environments under extreme climatic conditions, with shortage of pastures and low water supply (Barioglio et al., 1997; Hernández Zepeda et al., 2002; Lanari et al., 2003; Revidatti et al., 2007; Chacón et al., 2011; Gómez, 2013; Arias, 2015). Traditionally and nowadays, the productive orientation of goat livestock in the territory is based on the elaboration of goat cheese, together with the meat of the goat kids when weaned (Pizarro Silva, 2015).

The body architecture of livestock breeds including goats is an adaptive response to the environment (Sierra Alfranca, 2001). The body shape of the animal determines biological functionality ranges which are conditioned by the shape underlying the animal biotype (Toro Ibacache et al., 2010). Body measurements, which give significant information on morphologic structure and development ability of animals, are the most influential factors on determining animals that are appropriate for the desired efficiency, and on determination of whether the establishment is in development or recession. Moreover, they can be considered as morphologic characters that can provide comprehensive information to complete investigations on the performance of goat breeds (Parés-Casanova, 2007; Traore et al., 2008; Alpak et al., 2009; Yakubu, 2010). The respective coefficient of variation between breeds indicates the amount of opportunity available for improving the breeds through selection (Salako, 2006). In addition, variability in the morphometric architecture suggests diferent degrees of goat's adaptation to ecological conditions (Osaiyuwu et al., 2010; Gómez). For this reason, the phenotypic information could be serve as a basis for designing appropriate conservation, breeding and selection strategies for creole goats (Yakubu \& Ibrahim, 2011). In this regard, several authors point out that the use of multivariate analysis tools can be especially useful for describing local or long-lived animal populations (Hernández Zepeda et al., 2002; Deza et al., 2003; Zaitoun et al., 2004; Prieto et al., 2006; Chacón et al.;

\footnotetext{
${ }^{1}$ Instituto de Investigaciones Agropecuarias, INIA Remehue, Chile.
}

${ }^{2}$ Instituto de Investigaciones Agropecuarias, INIA Butalcura, Chile. 
Pires et al., 2013; Gómez; Abdala et al., 2014); this could allow to differentiate them from other populations, generating racial standards (Lanari et al.; Revidatti et al., 2007, 2013) and allowing them to be managed as specific genetic resources (Gómez; Abdala et al.; Parés-Casanova \& Kucherova, 2015).

The aim of this study was to asses the differentiation of body architecture between Creole goats, introduced breeds and their hybrids in the semi-arid region of Chile.

\section{MATERIAL AND METHOD}

The study was conducted between 2012 and 2015 . One hundred and eighty five adult female goats belonging to 17 herds were used. Ten animals of the Saanen breed and 10 animals of the Anglo Nubian breed belonging to two hatcheries and 165 Creole and hybrid goats belonging to small-farmers from Coquimbo region (29 $57^{\prime} 00^{\prime \prime} \mathrm{S}$ $71^{\circ} 20^{\prime} 00^{\prime \prime} \mathrm{W}$ ) were measured. The animals were categorized into pure breed (20), hybrid (52) and creole (113) according to their phenotypical features. Eight individual body measurements were taken: head length (HL), head width (HW), longitudinal diameter (LD), bicostal diameter (BD), dorsal-sternal diameter (DSD), rump width (RW), rump length (RL) and whithers height (WH). Data were submitted to principal component analysis (PCA) and Fisher LSD test, using the XLSTAT-Pro Statistic software.

\section{RESULTS AND DISCUSSION}

The PCA accounted for $61.7 \%$ of the body architecture variability of the total goat population considered in the study (Fig. 1). As is noted, there is a set of associated measures (BD, DSD, LD, RW, WH and HL) that express an explanatory similarity with respect to variability. On the other hand, the head width (HW) and the rump length (RL) have an own and distinctive variability. These two variables have been considered to be specially studied in order to identify which aspects of body architecture describe differentially within the population so that they can distance themselves from others in such a clear way (Parés-Casanova, 2009; Toro Ibacache et al.).

The correlation matrix is a tool that allows to identify common patterns of body architecture within the evaluated population (Sierra Alfranca; Parés-Casanova, 2009; Chacára et al., 2013). In the present study, the dorsal-sternal diameter (DSD) appears generating a standard relationship with all the other measurements (Table I). However, there are differences between variables that may be reflecting the existence of subsets of homogeneity within the population, since 23 of the 28 possible interactions were significant, but even so, they failed to reflect a common architectural pattern for the entire population, evidencing specific relationships between variables.

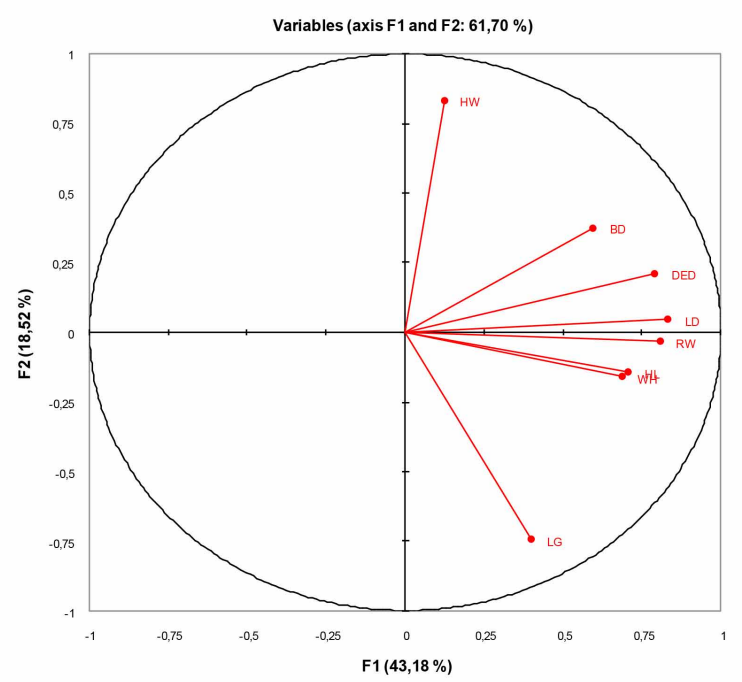

Fig. 1. Kepresentation in the ractorial prane or tne varıabiıty of morpho-structural measurements of evaluated goats according to PCA. HL: head length; HW: head width; WH: withers height; $\mathrm{BD}$ : bicostal diameter; LD: longitudinal diameter; RW: rump width; RL: rump length; DSD dorsalsternal diameter.

Table I. Correlations Pearson Matrix of morpho-structural measurements of the goat biotypes evaluated. Bold values are different from 0 with a significance level of alpha $=0.05$.

\begin{tabular}{lllllllll}
\hline Variable & HL & HW & LD & BD & DSD & RW & RL & WH \\
\hline HL & 1 & - & - & - & - & - & - & - \\
HW & 0,008 & 1 & - & - & - & - & - & - \\
LD & 0,459 & 0,139 & 1 & - & - & - & - & - \\
BD & 0,352 & 0,203 & 0,452 & 1 & - & - & - & - \\
DSD & 0,440 & 0,232 & 0,568 & 0,445 & 1 & - & - & - \\
RW & 0,457 & 0,040 & 0,618 & 0,396 & 0,549 & 1 & - & - \\
RL & 0,363 & $-0,364$ & 0,286 & 0,005 & 0,166 & 0,261 & 1 & - \\
WH & 0,324 & $-0,013$ & 0,547 & 0,204 & 0,509 & 0,530 & 0,267 & 1 \\
\hline
\end{tabular}


When analyzing in detail the variables that in Figure 1 showed a differentiated expression (HW and RL), it can be seen that HW shows significant correlations in three out of seven possible interactions, and with a degree of correlation lower than fifty percent. In the case of RL, there were six out of seven significant correlations, which indicates the approximation to a pattern, but the correlation between this variable and HW was negative, being the only inverse correlation that occurs.

Thus, it is possible that both body measurements describe a subset within the population with a different body architecture. In this sense, it is relevant to analyze if this describes differences related to belonging to racial subgroups or to hybridization within the population (Abdala et al.).

When body measurements within each group in the population and the significance of the differences were analyzed (Table II), the Creole biotype differed from the Saanen and Anglo Nubian breeds in all body measurements, with the exception of head width. In this way, the Creole biotype presents a smaller body architecture than these two breeds, which could be an adaptative response (Osaiyuwu et al.; Gómez). Regarding to the hybrids, they shown significant differences with the Creole biotype, showing a greater head length, a longer rump length and a greater withers height. In this sense, it is possible to affirm that the Creole biotype presents a differentiated body architecture compared to the breeds introduced to the region and also to the hybridized animals; therefore, it is possible to clearly identify this biotype within the goat population evaluated since it maintains distinctive characteristics (Lanari et al.; Gómez; Arias; Abdala et al.).

The different body architecture showed by the Creole goat biotype compared to the existing breeds and hybrids on this same semi-arid area, allows us to consider the possibility to rescue an Iberian origin type of goat with a long adaptation to the agroecological and geographical conditions of these semi-arid area. This makes possible the management of genetic resources to generate value around their products and also being a productive development platform for rural communities in the territory. In this sense, it is necessary to evaluate the adaptive aspects of this goat population and its production parameters in a scheme of production of animal by-products (e.g. meat and/or dairy products) with value of origin that allow to generate quality products and cultural identity. This could also be part of sustainable production systems based on a genetic resource adapted to the specific conditions of the area (Revidatti et al., 2013; Abdala et al.; Parés-Casanova \& Kucherova), and therefore, with a lower requirement for importing inputs external to the production system(Lanari et al.).

\section{CONCLUSIONS}

The results indicated the existence of homogeneity subsets within the goat population evaluated, without a common architectural pattern for the entire population. The Creole biotype showed a smaller body architecture than the two beeds and hybrids with which it was compared, which could be an adaptive response. It is possible to assess that the Creole biotype has a differentiated body architecture with respect to the introduced goat breeds and the animals hybridized in different proportions. It was observed that Creole goats maintain distinctive characteristics and they are differentiable even of the individuals with different degrees of hybridization.

ACKNOWLEDGMENTS. To the World Organization for Food and Agriculture (FAO) for the financing of the project "Strategies of in situ conservation of cattle and goats" that allowed to carry out this study. The authors also wish to thank Raúl Meneses for his technical and logistical support.

Table II. Mean values and standard deviation in body measurements of Creole, hybrid and breed goats evaluated.

\begin{tabular}{lllllllll}
\hline \multirow{2}{*}{ VARIABLE } & Creole & \multicolumn{3}{c}{ Saanen } & \multicolumn{3}{c}{ Anglo Nubian } & Hybrids \\
& Media & SD & Media & SD & Media & SD & Media & SD \\
\hline HL & $28,6 \mathrm{a}$ & 1,918 & $30,8 \mathrm{~b}$ & 1,439 & $29,7 \mathrm{~b}$ & 1,767 & $29,2 \mathrm{~b}$ & 1,449 \\
HW & $14,0 \mathrm{a}$ & 2,134 & $12,7 \mathrm{~b}$ & 0,652 & $12,9 \mathrm{~b}$ & 0,625 & $13,4 \mathrm{a}$ & 1,602 \\
LD & $73,5 \mathrm{a}$ & 4,653 & $80,7 \mathrm{~b}$ & 4,979 & $85,6 \mathrm{c}$ & 3,953 & $75,3 \mathrm{a}$ & 3,651 \\
BD & $17,7 \mathrm{a}$ & 2,083 & $20,7 \mathrm{~b}$ & 2,137 & $20,4 \mathrm{~b}$ & 2,025 & $17,9 \mathrm{a}$ & 1,782 \\
DED & $31,3 \mathrm{a}$ & 2,522 & $34,1 \mathrm{~b}$ & 0,959 & $34,7 \mathrm{~b}$ & 1,229 & $32,1 \mathrm{a}$ & 1,544 \\
RW & $19,8 \mathrm{a}$ & 1,286 & $21,5 \mathrm{~b}$ & 1,141 & $22,8 \mathrm{c}$ & 3,765 & $20,3 \mathrm{a}$ & 1,164 \\
RL & $14,3 \mathrm{a}$ & 1,232 & $16,1 \mathrm{~b}$ & 1,308 & $15,8 \mathrm{~b}$ & 1,438 & $15,6 \mathrm{~b}$ & 1,016 \\
WH & $68,0 \mathrm{a}$ & 3,241 & $72,7 \mathrm{~b}$ & 3,546 & $76,5 \mathrm{c}$ & 3,127 & $70,4 \mathrm{~d}$ & 3,771 \\
\hline
\end{tabular}

Within the same row, different letters indicate significant differences $(\mathrm{P}<0.05)$. 
DE LA BARRA, R.; CARVAJAL, A. M. \& MARTÍNEZ, M. E. Diferenciación poblacional en la arquitectura corporal de cabras criollas en la región semiárida de Chile. Int. J. Morphol., 37(2):690-693, 2019.

RESUMEN: El presente estudio tuvo por objetivo identificar si existe diferenciación en la arquitectura corporal entre caprinos Criollos, razas introducidas y rebaños hibridados con las mismas. El estudio se llevó a cabo entre 2012 y 2015 en la región de Coquimbo, Chile. Ciento ochenta y cinco cabras fueron estudiadas, pertenecientes a 17 rebaños distintos. Se midieron 10 animales de raza Saanen y 10 animales de raza Anglo nubian presentes en dos criaderos, y 165 animales Criollos e híbridos en predios de productores. Ocho medidas corporales fueron determinadas: longitud de la cabeza (HL), ancho de la cabeza (HW), diámetro longitudinal (LD), diámetro bicostal (BD), diámetro dorso-esternal (DSD), ancho de la grupa (RW), longitud de la grupa (RH) y alzada a la cruz (WH). Los datos de medidas se analizaron mediante análisis de componentes principales (PCA) y test LSD de Fischer con el programa estadístico XLSTAT Pro. Los resultados indican que las diferencias entre variables refllejan la existencia de subcojuntos de homogeneidad dentro de la población, no apreciándose un patron arquitectónico común para toda la población. De esta manera, el biotipo Criollo presenta una arquitectura corporal más reducida que las razas con las que se compara en este estudio, lo cual pudiera ser una respuesta adaptativa. En este sentido, es posible afirmar que el biotipo Criollo presenta una arquitectura corporal diferenciada respecto de las razas introducidas a la región y a los animales hibridados en distintas proporciones con dichas razas, con lo cual es posible observar que mantiene características distintivas y que es diferenciable incluso de distintos grados de hibridaje presente en dicha población.

PALABRAS CLAVE: Morfología; Cabra; Caracterización poblacional; Etnología animal.

\section{REFERENCES}

Abdala, G. C.; Valencia, R. D.; Lescano, J. A.; Abadala, M. E.; Alvarez, R. \& David, R. N. Aplicación del ACP para Diagnosticar la Absorción de la Raza Boer por Cabras Criollas, Mestizas y Anglo Nubian en Diferentes Estadios de Cruzamientos. Santiago del Estero, XIX Reunión Científica del Grupo Argentino de Biometría, 2014.

Alpak, H.; Onar, V. \& Mutus, R. The relationship between morphometric and long bone measurements of the Morkaraman sheep. Turk. J. Vet. Anim. Sci, 33(3):199-207, 2009.

Arbiza Aguirre, S. I. Producción de Caprinos. Ciudad de México, AGT, 1986.

Arias, B. Caracterización Morfológica de la Cabra Criolla del Ecuador en el Cantón Zapotillo, Provincia de Loja. Tesis para la obtención del título de Ingeniero Zootecnista. Riobamba, Facultad de Ciencias Pecuarias, Escuela Superior Politécnica de Chimborazo, 2015.

Barioglio, C. F.; Deza, M. C.; Arias, M.; Varela, L.; Bonardi, C. \& Villar, M. Evaluación de algunos parámetros reproductivos en cabras criollas. Agriscientia, 14:37-42, 1997.

Chacón, E.; Macedo, F.; Velázquez, F.; Paiva, S. R,; Pineda, E. \& McManus, C. Morphological measurements and body indices for Cuban Creole goats and their crossbreds. Rev. Bras. Zootec., 40(8):1671-9, 2011

Deza, C.; Bascur, I.; Pérez, G.; Díaz, M. P. \& Barioglio, C. F. Identificación de variables morfoestructurales y de polimorfismos sanguíneos para la caracterización de cabras criollas en el NO de Córdoba, Argentina. Agriscientia, 20:6977, 2003.

Gómez, N. Caracterización Estructural, Morfológica y Genética de la Población de Cabras Autóctonas de la Región Apurimac del Perú. Tesis Doctoral. Barcelona, Facultad de Veterinaria, Universidad Autónoma de Barcelona, 2013.
Hernández Zepeda, J. S.; Franco Guerra, F. J.; Herrera García, M.; Rodero Serrano, E.; Sierra Vázquez, A. C.; Bañuelos Cruz, A. \& Delgado, J. V. Estudio de los recursos genéticos de México: características morfológicas y morfoestructurales de los caprinos nativos de Puebla. Arch. Zootec., 51(194):53-64, 2002.

Lanari, M. R.; Taddeo, H.; Domingo, E.; Pérez Centeno, M. \& Gallo, L. Phenotypic differentiation of exterior traits in local Criollo Goat Population in Patagonia (Argentina). Arch. Anim. Breed., 46:347-56, 2003.

Osaiyuwu, O. H.; Akinyemi, M. O. \& Salako, A. E. Factor analysis of the morphostructure of mature Balami sheep. Res. J. Anim. Sci., 4(2):63-5, 2010.

Parés-Casanova, P. M. \& Kucherova, I. Caracteres morfoestructurales de una raza caprina recientemente recuperada. Rev. Investig. Vet. Perú, 26(2):159-65, 2015.

Parés-Casanova, P. M. Estudio comparativo entre diversas razas ovinas pirenaicas a partir del análisis de caracteres morfológicos. REDVET Rev. Electron. Vet., 8(4), 2007. Available from: http://www.veterinaria.org/revistas/redvet/n040407/ 040701.pdf

Parés-Casanova, P. Zoometría. En: Valoración Morfológica de los Animales Domésticos. Madrid, Ministerio de Medio Ambiente y Medio Rural y Marino, Gobierno de España, 2009.

Pires, L. C.; Machado, T. M. M.; Araújo, A. M.; da Silva, J. B. L.; Euclydes, R. F.; Costa, M. C. \& Olson, T. A. Cluster evaluation of Brazilian and Moroccan goat populations using physical measurements. Rev. Bras. Zootec., 42(10):71320, 2013.

Pizarro Silva, N. Descripción de la Situación Actual de la Producción y Comercialización de Queso de Cabra Producido por la Agricultura Familiar en la Región de Coquimbo. Tesis Doctoral. Santiago de Chile, Universidad de Chile, 2015.

Prieto, P. N.; Revidatti, M. A.; Capellari, A. \& Ribeiro, M. N. Estudio de Recursos Genéticos: Identificación de Variables Morfoestructurales en la Caracterización de los Caprinos Nativos de Formosa. Corrientes, Comunicaciones Científicas y Tecnológicas, Universidad Nacional del Nordeste, 2006. Available from: http://www.unne.edu.ar/unnevieja/Web/cyt/cyt2006/04-Veterinarias/ 2006-V-012.pdf

Revidatti, M. A.; De la Rosa, S. A.; Cappello Villada, J. S.; Orga, A. \& Tejerina, E. R. Propuesta de estándar racial de la cabra criolla del oeste Formoseño, Argentina. Actas Iberoam. Conserv. Anim., 3:111-22, 2013.

Revidatti, M. A.; Prieto, P. N.; de la Rosa, S.; Ribeiro, M. N. \& Capellari, A. Cabras criollas de la región norte Argentina. Estudio de variables e índices zoométricos. Arch. Zootec., 56(Supl. 1):479-82, 2007.

Salako, A. E. Application of morphological indices in the assessment of type and function in sheep. Int. J. Morphol., 24(1):13-8, 2006.

Sierra Alfranca, I. El concepto de raza: evolución y realidad. Arch. Zootec., 50(192):547-64, 2001.

Toro Ibacache, M. V.; Manríquez Soto, G. \& Suazo Galdames, I. Geometric morphometry and the biologic shapes study: from the descriptive morphology to the quantitative morphology. Int. J. Morphol., 28(4):977-90, 2010.

Traore, A.; Royo, L.; Fernández, I.; Alvarez, I. \& Goyache, F. Multivariate characterization of morphological traits in Burkina Faso sheep. Small Rum. Res., 80:62-7, 2008.

Yakubu, A. \& Ibrahim, I. A. Multivariate analysis of morphostructural characteristics in Nigerian indigenous sheep. Ital. J. Anim. Sci., 10(2):83-6, 2011.

Yakubu, A. Path coefficient and path analysis of body weight and biometric traits in Yankasa lambs. Slovak J. Anim. Sci., 43(1):17-25, 2010.

Zaitoun, I. S.; Tabbaa, M. J. \& Bdour, S. Differentiation of native goat breeds of Jordan on the basis of morphostructural characteristics. Small Rum. Res., 56(13):173-82, 2004.

\section{Corresponding author: \\ Maria Eugenia Martínez \\ Instituto de Investigaciones Agropecuarias INIA \\ Remehue \\ CHILE}

Email: eugemartinez.inia@gmail.com

Received: 03-10-2018

Accepted: 24-01-2019 